\title{
Foodborne IIIness
}

National Cancer Institute

\section{Source}

National Cancer Institute. Foodborne IIIness. NCI Thesaurus. Code C128351.

Any disorder that results from the consumption of food contaminated with an infectious agent or toxin. 